\title{
Panas pela of education: Desegregation of Muslim and Christian post-reconciliation at SMPN 4 Salahutu Liang and SMPN 9 Ambon
}

\author{
Anju Nofarof Hasudungan ${ }^{1^{*}}$ \\ ${ }^{1}$ Department of History Education, Universitas Sebelas Maret, Indonesia \\ * Corresponding author \\ E-mail address: anjunofarof@gmail.com \\ DOI: https://doi.org/10.21107/sml.v3i2.7854
}

\begin{tabular}{|c|c|}
\hline Article Info & A BStract \\
\hline $\begin{array}{l}\text { Keywords: } \\
\text { Panas pela } \\
\text { Education } \\
\text { Desegregation } \\
\text { Muslim-Christian } \\
\text { Ambon }\end{array}$ & $\begin{array}{l}\text { This article examines the process of desegregation through panas pela of } \\
\text { education at SMPN } 4 \text { Salahutu Liang and SMPN } 9 \text { Ambon. Panas pela of } \\
\text { education is a transformation of pela gandong local wisdom with the aim of } \\
\text { overcoming segregation in schools. Pela gandong is a bond of brotherhood } \\
\text { between the people of Maluku, regardless of religion, either Islam or Christian. } \\
\text { The implementation of panas pela of education has been started since } 2013 \\
\text { between SMPN } 9 \text { Ambon, whose students are } 99 \% \text { Christian/Catholic and } \\
\text { SMPN } 4 \text { Salahutu Liang, which are } 100 \% \text { Muslim students. This research } \\
\text { method uses qualitative research with a case study approach. Data collection } \\
\text { techniques used by observation, participation, literature review, interviews, } \\
\text { and documentation. Panas pela of education as a process of desegregation } \\
\text { is carried out in the form of joint activities such as sports fairs, scouts, iftar, } \\
\text { Christmas, student council activities and teacher exchanges. In addition, the } \\
\text { students also performed dances, songs, and poetry without any segregation } \\
\text { between them. In the midst of the current strengthening of polarization due } \\
\text { to political choices, the panas pela of education is present as a means of social } \\
\text { integration and evidence of the existence of harmonization between religious } \\
\text { adherents in Indonesia. }\end{array}$ \\
\hline
\end{tabular}

\section{Citation suggestion:}

Hasudungan, A. N. (2020). Panas pela of education: Desegregation of Muslim and Christian post-reconciliation at SMPN 4 Salahutu Liang and SMPN 9 Ambon. Simulacra, 3(2), 223-236. https://doi.org/10.21107/sml.v3i2.7854

Received 11 July 2020; Received in revised form 1 October 2020; Accepted 10 October 2020; Published online 25 November 2020. 


\section{Introduction}

The peaceful reconciliation of confict in Ambon (the capital of the Maluku province) was reached with the Malino II agreement on February 12, 2002. However, this condition is not yet ideal because it does not solve the problem of segregation based on religion, namely, Islam and Christian. Religious segregation is the main element that results in increasing alienation, misunderstanding, cultural conflict, and even violence among believers of different faiths ( $\mathrm{Hu}$ et al., 2019; Susewind, 2017). This was exacerbated by increasing populism and identity politics before, during, and after the Indonesia presidential elections in 2014 and 2019. As a result, the society was divided into two groups due to political choices. Differences in political choices are common, but using racial issues to gain power is undemocratic.

Post reconciliation in 2002, Ambon is still in a vulnerable condition because there is still segregation. So, at any time if a trigger arises, especially if the trigger is a racial provocation, then it is more likely that conflict will reoccur. The fragility of peace is caused by the absence of fulfilling the peace gaps which had not yet been resolved when the Ambon conflict reconciliation was reached. People who live in post-conflict situations are faced with two major challenges, namely economic recovery that has been damaged by conflict and reducing the risk of conflict to overcome the fragility of post-conflict peace that can cause recurring violence (Collier et al., 2008). The condition of Ambon peace which is still vulnerable can also be illustrated from the results of Amirrachman's research that people in Central Maluku is live in a separate religion. If we go to rural areas, the segregation is even more real because there are Muslim villages and Christian villages.
In Ambon city there is a Galunggung area dominated by Muslims and Batu Gajah that is dominated by Christians.

Before the conflict, there were still some Muslim households that lived in Christian areas and vice versa. But after the conflict they now live further apart in religion (Amirrachman, 2014). Attempts to desegregate have been carried out like the Instruction President of the Republic of Indonesia, Number 6 of 2003, concerning the Acceleration Post-Conflict Recovery of Development in Maluku Province and North Maluku Province, but the results are not very good (Ansori et al., 2014). Progress began to be seen when the government rebuilt trust among conflicting groups to provide assistance to institutions socio-culture in the conflict areas of Poso, Maluku and North Maluku. This is done in collaboration with NGOs, community social organizations, and universities (Badan Perencanaan Pembangunan Nasional, 2009). Currently the method is only done by the use of local wisdom pela gandong which was previously successful as a medium for conflict resolution (Hartanti, Lailiya, Khair, 2018; Bräuchler, 2017) and peace education (Amirrachman, 2014). Panas pela is as a way for desegregation between adherents of Muslim and Christians who started from the school community. Panas means to strengthen again. Pela is a family and brotherly relationship between two or more villages with different religions and gandong means siblings. The word pela comes from the Hoamoal peninsula (Seram Island) and was adopted in the Ambonese language. Pela's original meaning is 'must be finished' (Sholeh, 2013).

Qurtuby (2013) explains the alliance of Muslim and Christian leaders in building peace in Maluku should be developed again by revealing other parties involved 
in the peacebuilding process in Ambon. Therefore, the author examines how United Nations Development Programme (UNDP) institutionstogetherwithMalukunationaland local institutions such as Convey Indonesia, Pusat Pengkajian Islam \& Masyarakat (PPIM) Universitas Islam Negeri Syarif Hidayatullah Jakarta, and Ambon Reconciliaton and Mediation Center (ARMC) Institut Agama Islam Negeri (IAIN) Ambon were involved so that SMPN 9 Ambon and SMPN 4 Salahutu Liang Central Maluku Regency can celebrate five years of the implementation of the panas pela of education which has been started since 2013, and the peak of the celebration had been held on January 29, 2018. The two schools have carried out a brotherly bond called panas pela in the culture of the Maluku people and become a pilot project in the field of peace education in Ambon (Hasudungan, Sariyatun, Joebagio, et al., 2020).

So it is necessary to study how desegregation is carried out to lead to the peace by involving students in SMPN 9 Ambon and SMPN 4 Salahutu Liang, Central Maluku Regency, which is packed with local traditions called panas pela. It is important to know that these two schools represent the two religions that were at war during the Ambon conflict, namely Muslims and Christians. The SMPN 9 Ambon has a total of 1431 students with 99\% Christians/ Catholics while SMPN 4 Salahutu Liang has a total of 414 students with 100\% Muslims. The author's study objective is the implementation of the panas pela between SMPN 4 Salahutu Liang Central Maluku District and SMPN 9 Ambon. Because panas pela is conducted by two schools, it is referred to as panas pela of education.

Previously, panas pela of education (rewarming the brotherhood ties in the field of education) had been held at Institut Agama
Islam Negeri (IAIN) Ambon and Universitas Kristen Indonesia Maluku (UKIM) in 2016. The two universities with different religious identities took the oath of brothers in the world of education. Both universities are committed to maintaining peace and solidarity between Muslims and Christians in the city of Ambon in particular, and the Maluku province in general. Therefore, the objective of the implementation of the panas pela of education is to desegregate and maintain peace through Maluku students by internalizing the values of peace education derived from the local wisdom of pela gandong.

\section{Method}

This study used descriptive qualitative research method with plural case studies approach. The research was conducted in January 2018 and continued in November 2019. The school was chosen because it has implemented the panas pela of education since 2013 and has become representative and concrete evidence of segregation between schools based on religion. Teacher exchange is carried out every month. Scout activities, sports week and others are carried out when there is a joint program. Meanwhile, iftar and Christmas together are held every year. Stake (1995) and Yin (2003) base their approach on case studies on the constructivist paradigm. Constructivists claim that truth is relative and depends on one's perspective. This paradigm "recognizes the importance of creating subjective human meanings, but does not directly reject the notion of objectivity.

The advantage of this approach is the close collaboration between researchers and participants while allowing participants to tell their stories (Crabtree \& Miller, 1999). 
Through these stories the participants can describe their views about reality and this allows researchers to better understand the actions of the participants (Lather, 1992; Hart \&Robottom, 1993). Data collection techniques used by observation, participation, literature review, interviews, and documentation.

The informants came from SMPN 4 Salahutu Liang and SMPN 9 Ambon City, and they consists of teachers, students, and principals. In addition, researchers also interviewed religious and community leaders in order to get a description of the research object. Informants from teachers were selected based on the social studies field of study, student grade level, and religion. This way of processing data and information was then termed the descriptive analytical method. This analysis and interpretation was carried out by referring to the theoretical foundation related to the research problem. However, in this study, the researcher used interactive data analysis from Miles and Huberman, namely: (1) data reduction, (2) data display, and (3) conclusion and verification (Miles \& Huberman, 1994). Data reduction is an activity to re-summarize field notes by selecting main points and focusing on important matters related to research problems, namely, Muslims and Christians desegregation through panas pela of education after the Ambon conflict.

\section{Results and Discussion}

\section{Desegregation of Muslims and Christians in Ambon}

Wulangsari (2014) explains that from a sociological perspective, segregation is the absence of interaction between social groups. Therefore, desegregation must begin by restoring interaction between social groups.
Community settlements that are built on the basis of a homogeneous and exclusive group identity of course have a negative impact. Sociologically, this can cause suspicion and social problems to trigger conflict. Even though it is hoped that the environment around the residents must be inhabited by various religions. This results in social integration and opportunities to protect and understand each other. Segregation is closely related to concepts such as polarization, stratification and inequality (Gorard \& Taylor, 2002). According to Cambridge Dictionary (2020), segregation is the policy of keeping one group of people separate from another and treating them differently, mainly because of race, gender, or religion.

Segregation occurs because a policy is not a social reality. Religious segregation occurs as a form of social phenomenon, and arises from legal decisions whether it is explicit or implicit. In this context, the current segregation is a situation that has not been able to be resolved when a peaceful reconciliation is reached through the February 2002 Malino Agreement. As stated by Aritonang (2004), after the Malino II Agreement document was signed, riots continued in Ambon City with the arrival of Laskar Jihad. They burned Universitas Kristen Indonesia Maluku (UKIM), damage to Pattimura University, and several churches. In other words, this agreement failed to reconcile the Muslims and Christians in Ambon.

Rivkin (2000) explains voluntary and enforced compliance by school districts has reduced the segregation of U.S. public schools. In the context of this research, efforts to reduce segregation are not only expecting voluntary compliance or enforcement by school regulations. However, this also happens because of the local wisdom values 
of pela gandong that are held firmly by the people of Maluku, especially when the people of Maluku revitalize pela gandong and succeed in becoming a conflict resolution. Desegregation, to be termed successful, must have eliminated widely-held racial stereotypes, broadened the cultural values transmitted by the schools, and increased the access of minority children to quality educational programs-the conduit to preferred colleges and jobs (Orfield, 2018). Panas pela of education has succeeded in being a means of social integration among students of different religions because it integrates cultural values and eliminates existing racial stereotypes. Pela gandong local wisdom values such as multiculturalism, harmonization, and brotherhood are the basis for implementing panas pela of education.

\section{Segregation among youth in Ambon}

Conflict does not only affect the group but also the individuals. This is the story of Ronald Regang (Former Christian Forces Combatant who was then 10 years old, Laskar Kristus in Indonesian) and Iskandar Slamet (15-year-old Muslimic Jihad Forces, Laskar Jihad in Indonesian) aired on August 16, 2018 on Rosi on the national television station Kompas TV for an episode of independence "Belajar Damai dari Maluku". These two young people are victims and perpetrators of violence during the Ambon conflict. The indoctrination that the conflict was a holy war became their main motivation to join this bloody conflict.

According to Ronald (Sahid et al., 2018) "The existence of war rituals are followed by obedience. Not looting, not saying dirty words, and not getting drunk, because it is contrary to Christian values. That behavior is considered to pollute the sanctity of struggle, and the consequences will be fatal if violated. Before heading to the war area, they asked for blessings from the priests. They perform special rituals. On the neck they hung a small Bible that was believed to be a sacred shield in battle. While Iskandar said that he hated Christians the most because his brother's leg was destroyed and his cousin died during the war against the Laskar Christ (Nurdin, 2018b). Ronald Regang and Iskandar experienced the Ambon conflict firsthand but many young people did not experience the Ambon conflict as a personal experience. But the "inheritance" of conflict survivors (parents, the community around the house, etc.), the narrative is quite significant in building a segregative mindset between groups in Ambon City.

Particularly among young people there is a narrative that reveals that the enemy group is the cause of the conflict and the group itself is the victim. This thought is widely believed by the Ambonese Youth. It should be noted that during the Ambon Ambon conflict there were two organized warring groups dominated by young people. Namely, Laskar Jihad and Laskar Kristus. Laskar Jihad is grouped under the umbrella of the Ahlus Sunnah Wal Jama'ah Foundation, a Salafi Muslimic group based in Java whose mission is known for fighting Christians (International Crisis Group, 2000). Laskar Jihad was formed in January 2000 and its leader, Ja'afar Umar Thalib, announced on April 6, 2000 at the Jakarta Senayan Stadium that they would invade Moluccas to help Muslims fight Christians. It is estimated that there are more than 3,000 members of Laskar Jihad. They operated in Ambon when the conflict occurred. Whereas Laskar Kristus or Christ's Forces claim to be fighters who defend their faith as God's army. Its leader is Agus Wattimena and this 
group consists of around 20,000 members. Some Ambonese Christian youths expressed strong enthusiasm for militant action, but many Christian leaders and members of Maluku churches preferred to focus on local efforts to restore peace and condemn militant actions. Laskar Kristus presents a war that is often described as a crusade mission against Muslims (Turner, 2006). In the opinion of Adam (2013) violence in the capital of Maluku is not only the most bitter but also the first brutal conflict in post-New Order Indonesia. Adam classified the Maluku conflict as "high intensity and protracted", due to a large number of direct killings.

The survey conducted by Hanry Harlen Tapotubun in 2019 revealed what was in the minds of Maluku youth (Hanry Harlen Tapotubun, 2019) as follows: Mamu (16 years old, Muslim), for example, said that the Ambon conflict was a Christianization agenda, so it became a necessity to keep suspicious of Christians. Alfin (17 years old, Christian) and Justin (15 years old, Christian) said that during the conflict many Christians were forced to become Muslims. The narratives understood by young people from both sides are quite dominated by conflict-filled narratives, with a variety of personal stories to justify their claims. These narratives make Laskar Kristus on the Christian side and Laskar Jihad on the Islamic side have to kill each other. Their success was when they managed to kill many enemies.The vortex of the Ambon conflict was so deep that the two troops could only choose two decisions: kill or be killed. If these negative prejudices and past grudges are not resolved immediately, this can be a cause of similar conflicts in the future. In the Maluku context as revealed by Christian activist Reverend Jack Manuputty (Nurdin, 2018a) "there is still a $40 \%$ to $50 \%$ potential for conflict like 1999, so we must continue to strengthen through a strategy of peace provocation and increasing friends." Young people, they become live 'ammunition' to prevent conflicts from happening. The return to power of political conservatives brought an end to the splendid efforts to desegregate public school systems to achieve racial equity and reconciliation, and often undermined the ongoing pursuit of a just and fairer American society (Drone, 2005). Although Indonesia has also experienced a strengthening of conservative politics in the last decade, the process of desegregation has not stopped and reconciliation continues because it is carried out with a cultural approach, namely, panas pela of education.

\section{Panas Pela of education as desegregation strategy}

Ruhulessin (2019) stated that one of the challenges of religions (Islam and Christian) in Maluku at this time is to seek and find common ground. Then he offered pela as a common ground capable of helping and empowering religions to carry out humanitarian tasks in overcoming common humanitarian crises in order to create a just, peaceful, equal and prosperous society. The existence of a common ground apart from differences also has some similarities which can be used as a basis for building trust (Dijk, 2004). In essence, pela belongs to every Maluku person, whether Muslim or Christian. However, the Ambon conflict has made the people of Maluku experienced segregation and distrust each other. Therefore, before building common ground, first desegregation and rebuilding mutual trust between Muslims and Christians should be carried out. Without the medium to facilitate social interaction and build trust, 
it will be difficult to build a common ground. Therefore, local wisdom of pela gandong is transformed into panas pela of education as a medium for social interaction, building mutual trust and in the end there will be a common ground, starting with the students.

Panas pela of education is carried out to desegregation between followers of Islam and Christian represented by SMPN 4 Salahutu Liang and SMPN 9 Ambon. The current segregation is not only a form of conflict reduction but also a legacy from the Ambon conflict reconciliation that has not been resolved and this will be a potential for conflict in the future. For the sake of common interests, the conflict is immediately resolved even though it is sometimes classified as entering a small conflict, but the friction is always there and it can eventually become big and detrimental to various parties (Wandi, 2019).

Desegregation is a concept that seems simple. This can be defined as a process through which previously separated group members can be put back together, often through removing formal barriers to interaction. This concept gained historical significance largely through its relationship with political movements such as the Civil Rights Movement in the United States and movements against apartheid in South Africa, which, among other objectives, fought for the abolition of the racial segregation legal system. Desegregation may be the only educational policy that has improved academic and social outcomes for colored students at the system level in American public schools (Hilbert, 2017). Research results from Granovetter (1986) reveal that the success of desegregation is at least moderate inter-racial friendship and a reduction in trans-racial intolerance, reduced ethnic hostility - increased openness to individuals and other group cultures is inherently an advantage worth pursuing.

The implementation of local wisdom panas pela of education is an effort of desegregation by integrating the residents of the SMPN 9 Ambon and SMPN 4 Salahutu Liang who differ in equality, brotherhood and togetherness. The integration automatically impacts the elimination of the segregation structure but also seeks to overcome more than diversity in terms of numbers (Hilbert, 2017). The concept of social integration, as discussed by some social scientists, should show authentic forms of social relations; recognize, trust and equal (Varshney, 2003).

Parekh (2008) explains that the process of social integration in a democratic society requires three things. First, there is agreement from most of its members on certain social values that are fundamental and important. Second, society is gathered in various social units that supervise each other in potential social aspects. This is to prevent the domination and control of the majority group over the minority.

Table 1.2 Students based on religion

(Kementerian Pendidikan dan Kebudayaan Republik Indonesia, 2018)

\begin{tabular}{|c|c|c|c|}
\hline \multirow{2}{*}{ School name } & \multirow{2}{*}{ Total students } & \multicolumn{2}{|c|}{ Percentage of Students Based on Religion } \\
\hline & & Muslim & Christian \\
\hline $\begin{array}{l}\text { Public Junior High School (SMPN) } 9 \text { Ambon City Maluku } \\
\text { Province }\end{array}$ & 1431 & $1 \%$ & $99 \%$ \\
\hline $\begin{array}{l}\text { Public Junior High School (SMPN) } 4 \text { Salahatu Liang } \\
\text { Central Maluku Regency Maluku Province }\end{array}$ & 414 & $100 \%$ & $0 \%$ \\
\hline
\end{tabular}


Third, there is interdependence among social groups that are gathered in society to meet the overall economic and social needs. The main capital for the birth of social integration in a democratic society is the existence of a situation where people can communicate and interact with one another in an egalitarian, trusting and needy manner. According to (Varshney, 2003) such situations occur through civic engagement, both through interactions driven by civil society groups (organizing civic networks), as well as interactions that occur naturally through egalitarian public spaces (everyday civic networks). The two processes trust each other which causes different groups in the community will not engage in violent activities to the other. Social integration also requires recognition of the existence of differences and the right to live in society. With this recognition, a tolerant attitude towards diversity is born. Another important requirement as mentioned by Parekh (2008) is a moral contract such as shared values that bind the community in balance.

Panas pela of education can be a place for interaction and integration social. Because in the past this has been done by the ancestors of the Maluku. The "panas pela" program is usually held to increase and strengthen the relationship between villages that have a cultural tradition of "pela-gandong", a tradition that establishes brotherhood between communities of different religions. The superiority of pela gandong culture in Maluku is seen not only in the portion of the administrative area but the meaning of the essence of the pela gandong itself. Pela gandong has a cultural advantage which is also referred to as a culture of peaceful harmony based on kinship in the concept of local wisdom that is present because it was initiated from the intelligence of the Maluku ancestors.

The values of pela gandong namely, first, concepts; live people Basudara (human brothers), Potong di kuku rasa di daging (help each other), Ale Rasa Beta Rasa (have empathy with others), Sagu salempeng dipata dua (a life of caring and sharing), Ain ne ain (belong to one another), Kalwedo (legal evidence of ownership of indigenous people, joint ownership), Kidabela (one heart, one feeling and one family), Sitakaka walike (a brotherhood that lives in harmony and peace) and so forth. All of these local values are local content packaged in a tradition of harmonization of brothers in Maluku. Second, pela gandong has become a social institution that develops as glue for social relations between Muslim villages and Christian villages. Third, pela gandong is very functioning in regulating the system of social interaction of indigenous peoples that transcends various fields. Four, pela gandong as a model of friendship or brotherhood system, or a system of fellowship that was developed between all indigenous people from two or more villages. The system ties have been established by the ancestors in special circumstances with certain rights and obligations agreed upon (Hasudungan, Sariyatun, \& Joebagio, 2020).

Panas pela means 'reunion' which aims to re-warm the relationship of brotherhood (pela) and sibling (gandong). Panas pela is done by holding a ceremony that is done regularly. At such events, village partners gather in one village for about a week to celebrate their unity. The panas pela of education activity aims to further strengthen the brotherly relations of students in both schools with different religious backgrounds, namely, Muslims and Christians. Paul 
Lederach stated that the greatest resource for sustaining peace in the long run is always rooted in the local population and their culture (Collier et al., 2008). To maintain the existence of the pela, and to make adolescents aware of their obligations, is also the aim of implementing panas pela. Many pela alliances regularly hold ceremonies to "Memanaskan Pela" (strengthen brotherhood). On this occasion, people from pela members met in one village for a week to celebrate their union, accompanied by a renewal of oaths, parties, singing and dancing. In addition to feeling a concrete situation in daily life, they are as Maluku children but also to build character and identity as village children who have moral values and brotherhood (Salenussa \& Mataheru, 2019). Pela is still maintained through a panas pela ceremony which is held once in 5 or 20 years depending on joint decisions. The ceremony aims to remind people of the alliance between the villages. Villages that panas pela are not bound by religion. Many Muslim villages have pela with Christian villages. Indigenous alliances are reflected in activities such as building places of worship and helping people suffering from disasters (Torell \& Salamanca, 2002).

Looking at various things that have happened in Maluku, such as the religious conflict in 1999-2002, so that the people of Maluku, especially in Ambon City experienced challenges in the concept of harmony "orang basudara" (People of Maluku Brothers). The importance of education and culture are not only two inseparable sides but two complementary sides to be used as cultural instruments in growing the personality of every child in Maluku. The process to restore stability and peace is ongoing slowly but surely. Recovery can only be effective when pela is reconstructed according to actual needs and demands and to stimulate panas pela. By reawakening the panas pela spirit of the Maluku as the identity of the people of Maluku is needed, inseparable inheritance is not only a meaningless inheritance but has its meaning that can be applied at any time to the younger generation (Usta'adza et al., 2019). For this reason, the initiative of the citizens of SMPN 9 Ambon and SMPN 4 Salahutu Liang Maluku schools to start a new era by carrying out panas pela, the main goal is how students in these two schools with different religious embraces can learn to live together and tolerate with a local wisdom approach. No longer inheriting hatred and inner wounds caused by conflict. Questioning how the history of local wisdom pela gandong transformed into the field of education to be called the panas pela of education. Henny Liklitiwatil, teacher of SMPN 9 Ambon explains in detail as follows:

"The formation of the pela of education between SMPN 4 Salahutu Liang and SMPN 9 Ambon City, started because of the segregation after the Ambon conflict in 1999. Therefore, when reconciliation also affects segregation in terms of residence, it means that the Muslim community lives in a Muslim place, the Christian community lives in a Christian place, it also affects the world of education. This means that Muslim students also attend schools in Muslim areas as well as Christian students attend schools in Christian areas. Thus, there was no meeting between Muslim students and Christian students. The incident continued unabated, so that in 2013 there were teachers who were in the city of Ambon and Central Maluku Regency called to attend education, training, on how teachers became agents of peace. Teachers are called to participate in training activities, after that we also carry 
out a live-in program. So when living in, Christian teachers live in Muslimic areas as well as Muslim teachers live in Christian areas".

Segregation is a problem that has not been able to be resolved after the peace agreement was reached in 2002. Segregation can also threaten Ambon's peace in the future if it cannot find a solution. Peace activists and organizations carry out the panas pela of education as desegregation strategy in the field of education and involve students from two religious groups (Muslims and Christians).

Then why was the education sector chosen to be a means of implementing panas pela as the desegregation of SMPN 9 Ambon and SMPN 4 Salahutu Liang, Central Maluku Regency. The following is an explanation from SMPN 4 Salahutu Liang teacher, Muhammad Yusuf:

"This pela-based desegregation has been around for a long time. Local-based desegregation because we show a lot of local wisdom there. That pela does not have to be outside, it does not have to be in the community. Pela it must be at school we also build the character of students. This is a new thing when pela is applied in the field of education. The reason why pela is applied in the field of education, the goal is that students have the spirit of how to arouse togetherness and brotherhood in pela, in social relations, in social relations. Therefore, it is important for the development of their lives and peace in Ambon City and Maluku Province in the future".

Meanwhile, according to Dimara Dinasti Laga (Muslim) who is the Chairperson of the student council of SMPN 4 Salahutu Liang added his opinion about pela gandong. The following is the explanation:
"The teacher Muhammad Yusuf explained to us all that pela gandong is a cultural ancestor of the Maluku. SMPN 4 and SMPN 9 are the heirs of the Maluku ancestors. In learning social studies we were told by the teacher that when we want to make peace from the conflict, pela gandong becomes the intermediary of the warring groups. A concrete example of the strength of the Maluku ancestors. We students now are more familiar with pela gandong. I am very happy to be able to gather, make activities together, Christmas together, Happy Eid Mubarak together, Scouts and Student Sports Activities with friends from Ambon City SMPN 9 like Jack Dea. We both became the Chairman of the Student Council and should be an example to other friends that even though we are of different faiths we can be friendly and united. It's all because of pela gandong, Ale Rasa Beta Rasa (have empathy with others)".

While the chairman of the student council of SMPN 9 Ambon, Jack Dea (Christian) explained as follows:

"We are all brothers (gandong). Through this
gandong bond we are all brothers. SMPN 9
Ambon and SMPN 4 Salahutu Liang Even
though we have different religions (Christian
and Islam) we can still be friends, get
together and get to know each other. With
pela gandong we no longer see differences as
a problem because our ancestors have long
been brothers and sisters, please help. We
have to preserve it".

Raspberry (1980) explains segregation (by now generally recognized as an evil thing) is the arbitrary separation of people on the basis of their race, or some other inappropriate characteristic, desegregation is simply the ending of that practice. The implementation of panas pela of education at SMPN 4 Salahutu Liang and SMPN 9 Ambon is a practice to end segregation. 
Implemented in form namely: first, various cultural attractions displayed by students from both schools such as dance, song, and poetry, all lead and invite students to live with one another to love each other even though different religions, tribes, and groups. Second, it carry out many joint activities including sports and art competitions, scouts, iftar together, Christmas together, student council activities to the exchange of teachers to teach at school. Third, two schools were also part of the Peace Provocator filmmaking in 2013 as a form of peace and multicultural campaign.

Actual integration requires more than diversity in the student body; but also an inclusive curriculum and diverse teaching staff. Regarding teacher exchanges, the aim is to break down negative prejudice by presenting teachers and students from various religions in the class. For example, Christian teachers from SMPN 9 Ambon who come to SMPN 4 Salahutu Liang to teach. And also done by Islamic teachers from SMPN 4 Salahutu Liang to teach at SMPN 9 Ambon. This is intended so that teachers and students of different religions can understand each other so that differences do not make the two adherents hate each other, but rather tolerance will arise and harmony will be created in these differences.

\section{Conclusion}

Pela gandong is a bond of brotherhood that has been carried out by the ancestors of the Maluku people before the colonial era, and continues to be renewed by each generation until today. Panas pela was carried out with the intention of reminding the brotherhood. After the reconciliation of the Ambon conflict was achieved on February 12, 2002, efforts were made to continue building peace. The segregation that occurs postreconciliation becomes a potential conflict in the future if desegregation is not carried out. The transformation from pela gandong local wisdom to panas pela of education is evidence of the dynamism of local wisdom and being able to adapt to the times without losing one's identity. Even at the time of the Ambon conflict, pela gandong became a media for conflict resolution.

Panas pela of education is the desegregation of Islam and Christian which begins at SMPN 4 Salahutu Liang and SMPN 9 Ambon. The desegregation does not depend only on big figures or formal legal rules, but rather on local wisdom. The two schools were chosen because of the existence of pela gandong as a common ground and strong evidence that segregation exists, two schools become representatives of two religions (Islam and Christian) which were previously been in conflict. Panas pela of education is carried out in various kinds of activities and programs together. Namely, sports competitions and art fairs, scouts, iftar, Christmas, student council and teacher exchanges. On various occasions, the two schools also performed dances, songs, and poetry. All students can do all that without segregation, mingling with each other and in brotherhood. Panas pela of education in the two schools has become a symbol and inspiration not only for the people of Maluku but for Indonesia that there is still tolerance, pluralism, and living in harmony despite different religions. It is hoped that panas pela can be implemented in other fields in order to create a better civil society.

\section{Declaration of Ownership}

This article is our original work. 


\section{Conflict of Interest}

There is no conflict of interest to declare in this article.

\section{Ethical Clearance}

This study was approved by the institution.

\section{References}

Adam, J. (2013). A comparative analysis on the micro-level genealogies of conflict in the Philippines' Mindanao island and Indonesia's Ambon island. Oxford Development Studies, 41(2), 155-172. https://doi.org/10.1080/13600818.2013.78 9841

Amirrachman, A. (2014). Education in the conflict-affected Moluccas local tradition, identity politics and school principal leadership. South East Asia Research, 22(4), 561-578. https://doi.org/10.5367/ sear.2014.0235

Ansori, M. H., Sukandar, R., Peranto, S., Karib, F., Cholid, S., \& Rasyid, I. (2014). Segregasi, kekerasan dan kebijakan rekonstruksi pasca konflik di Ambon. The Habibie Center.

Aritonang, J. S. (2004). Sejarah perjumpaan Kristen dan Islam di Indonesia. BPK Gunung Mulia.

Badan Perencanaan Pembangunan Nasional. (2009). Pidato kenegaraan tahun 2009. www.bappenas.go.id. https://www. bappenas.go.id/id/data-dan-informasiutama/dokumen-perencanaan-danpelaksanaan/pidato-kenegaraantahun-2009/

Bräuchler, B. (2017). Dimensi budaya dalam perdamaian. Ombak.

Cambridge Dictionary. (2020). Segregation. Cambridge University Press. https:// dictionary.cambridge.org/us/dictionary/ english/segregation
Collier, P., Hoeffler, A., \& Söderbom, M. (2008). Post-conflict risks. Journal of Peace Research, 45(4), 461-478. https://doi. org/10.1177/0022343308091356

Crabtree, B. F., \& Miller, W. L. (1999). Doing qualitative research (2nd ed.). Sage Publications, Inc.

Dijk, T. A. van. (2004). Discourse, knowledge and ideology: Reformulating old questions and proposing some new solution. Communicating Ideologies, 5-38. http://www.discourses.org/OldArticles

Drone, J. (2005). Desegregation and effective school leadership: Tracking success, 1954-1980. The Journal of African American History, 90(4), 410-421. http://www.jstor. org/stable/20064021

Gorard, S., \& Taylor, C. (2002). What is segregation? A comparison of measures in terms of "strong" and "weak" compositional invariance. Sociology, 36(4), 875-895. https://doi. org/10.1177/003803850203600405

Granovetter, M. (1986). School desegregation research new directions in situational analysis (J. Prager, D. Longshore, \& M. Seeman (eds.). Plenum Press. https://doi. org/10.107/978-1-4613-2135-4

Hanry Harlen Tapotubun. (2019). Pewarisan narasi konflik dan tantangan rekonsiliasi di Ambon. https://crcs.ugm.ac.id/ pewarisan-narasi-konflik-di-ambon/

Hart, P., \& Robottom, I. M. (1993). Research in environmental education: Engaging the debate. UNSW Press.

Hartanti, N.L., Khair, F.K., \& Aini, Z. (2018). Pela gandong: Sara conflict resolution method base on local wisdom in Mollucas. 336-342.

Hasudungan, A. N., Sariyatun, Joebagio, H., \& Sartika, L. D. (2020). Transformasi kearifan lokal pela gandong dari resolusi konflik hingga pendidikan perdamaian di Maluku. Fikri: Jurnal Kajian Agama, 
Sosial dan Budaya, 5(1), 37-50. https://doi. org/https://doi.org/10.25217/jf.v5i1.784

Hasudungan, A. N., Sariyatun, S., \& Joebagio, H. (2020). Pengarusutamaan pendidikan perdamaian berbasis kearifan lokal pela gandong pasca rekonsiliasi konflik Ambon di sekolah. Jurnal Lektur Keagamaan, 17(2), 409. https://doi. org/10.31291/jlk.v17i2.664

Hilbert, J. (2017). School desegregation 2.0: What is required to finally integrate America's Public Schools. SSRN Electronic Journal, 16(1). https://doi. org/10.2139/ssrn.3031618

Hu, J., Zhang, Q. M., \& Zhou, T. (2019). Segregation in religion networks. EPJ Data Science, 8(1). https://doi.org/10.1140/ epjds/s13688-019-0184-x

International Crisis Group. (2000). Indonesia's Maluku crisis: The issues. https://www. crisisgroup.org/asia/south-east-asia/ indonesia/indonesias-maluku-crisisissues\#

Kementerian Pendidikan dan Kebudayaan Republik Indonesia. (2018). Sekolah kita. http://sekolah.data.kemdikbud.go.id

Lather, P. (1992). Critical frames in educational research: Feminist and post-structural perspectives. Theory Into Practice, 31(2), 87-99. https://doi. org/10.1080/00405849209543529

Miles, M. B., \& Huberman, A. M. (1994). Qualitative data analysis: An expanded sourcebook, 2nd edition (2nd ed.). Sage Publications.

Nurdin, E. (2018a). Persahabatan pendeta dan ustad mengantar mantan tentara anak Ambon menjadi duta damai. BBC Indonesia. https://www.bbc.com/ indonesia/indonesia-43521909

Nurdin, E. (2018b). Saling bunuh, saling bakar sampai... 'sayang kamu semua': mantan tentara anak Islam dan Kristen Ambon. BBC Indonesia.
Orfield, G. (2018). How to make desegregation work: The adaptation of schools to their newly-integrated student bodies. In The courts, social science, and school desegregation. Routledge.

Pamungkas, C. (2014). Agama, etnisitas, dan perubahan politik di Maluku: Refleksi teoretik dan historis. Masyarakat Indonesia, 40(1), 37-56. https://doi.org/ https://doi.org/10.14203/jmi.v40i1.105

Parekh, B. (2008). Rethinking multiculturalism, keragaman budaya dan teori politik. Kanisius.

Qurtuby, S. A. (2013). Peacebuilding in Indonesia: Christian-Muslim alliances in Ambon island. Islam and ChristianMuslim Relations, 24(3), 349-367. https:// doi.org/10.1080/09596410.2013.785091

Raspberry, W. (1980, December 1). The difference between desegregation and integration. The Washington Post. https:// www.washingtonpost.com/archive/ politics/1980/12/01/the-differenceb e twe en - d e s e gregation-and integration/7af50057-1ae1-4f30-8fd7$96 \mathrm{e} 025 \mathrm{ac} 39 \mathrm{~b} 0 /$

Rivkin, S. G. (2000). School desegregation, academic attainment, and earnings. The Journal of Human Resources, 35(2), 333. https://doi.org/10.2307/146328

Ruhulessin, J. C. (2019). Paradigma etika publik dalam kearifan lokal pela. Jurnal Filsafat, 29(2), 183-205. https://doi.org/ https://doi.org/10.22146/jf.36344

Sahid, A. N., Rubianti, F., Mubarok, H., Wahyuningroem, S. L., Bagir, Z. A., Rafsadie, I., \& Manuputty, J. (2018). Keluar dariekstremisme: Delapan kisah "hijrah" dari kekerasan menuju bina damai (I. A. Fauzi \& D. A. Kartika (eds.). Pusat Studi Agama dan Demokrasi (PUSAD) Paramadina. https://www.paramadina-pusad.or.id/ buku/keluar-dari-ekstremisme/

Salenussa, B. J. M., \& Mataheru, N. M. (2019). Development of integration education 
model pela-gandong local based on local content in primary schools in Ambon city. 2, 118-127. https://doi.org/10.35940/ijrte. B1027.0982S919

Sholeh, B. (2013). The dynamics of Muslim and Christian relations in Ambon, Eastern Indonesia. International Journal of Business and Social Science, 4(3), 303311. http://www.ijbssnet.com/journals/ Vol_4_No_3_March_2013/32.pdf

Stake, R. E. (1995). The art of case study research. Sage Publications, Inc.

Susewind, R. (2017). Muslims in Indian cities: Degrees of segregation and the elusive ghetto. Environment and Planning A, 49(6), 1286-1307. https://doi. org/10.1177/0308518X17696071

Torell, M., \& Salamanca, A. M. (2002). Institutional issues and perspectives in the management of fisheries and coastal resources in Southeast Asia. ICLARM - The World Fish Center, Jalan Batu Maung, Batu Maung, 11960 Bayan Lepas, Penang, Malaysia and Swedish International Development Cooperation Agency (Sida), S-105 25 (Office: Sveavagen 20, Stockholm), Stockholm, Sweden.

http://pubs.iclarm.net/Pubs/institutional_ sea/pub_insea0.pdf

Turner, K. T. (2006). Competing myths of nationalist identity: Ideological perceptions of conflict in Ambon, Indonesia [Murdoch
University]. https://researchrepository. murdoch.edu.au/id/eprint/374/

Ulafor, O. J. (2020). Martin Luther King Jr's philosophy of non-violence: A paradigm for global black race towards conflict resolution and peace in Africa. Jurnal Sosialisasi: Jurnal Hasil Pemikiran, Penelitian dan Pengembangan Keilmuan Sosiologi Pendidikan, 7(1), 54. https://doi. org/10.26858/sosialisasi.v0i0.13889

Usta'adza, L. S., Hartanti, N. L., \& Azizah, A. N. (2019). Building local wisdom identity through panas pela in Mollucas. Proceeding Book 7th Asian Academic Society International Conference 2019, 265268. http://aasic.org/proc/aasic/article/ download $/ 487 / 484$

Varshney, A. (2003). Etnic conflict and civic life: Hindus and Muslims in India ( $2^{\text {nd }}$ ed.). Yale University Press.

Wandi, W. (2019). Konflik sosial Suku Anak Dalam (Orang Rimba) di Provinsi Jambi. Simulacra, 2(2), 195-207. https://doi. org/10.21107/sml.v2i2.6034

Wulangsari, A. (2014). Segregasi permukiman berdasarkan faktor dan pola permukiman di Solo Baru, Sukoharjo. Jurnal Pembangunan Wilayah E Kota, 10(4), 387. https://doi.org/10.14710/ pwk.v10i4.8166

Yin, R. K. (2003). Case study research: Design and methods (3rd ed.). Sage Publications. 